DOI: 10.15503/onis2012-291-296

\title{
Przerażające i satyryczne obrazy Czarownic W LITERATURZE ŁACIŃSKIEJ
}

\author{
Anna Magdalena WoleK \\ Divus_iulius@poczta.fm
}

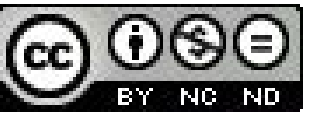

Temat magii i praktykujących ją osób jest bardzo popularny w dzisiejszej popkulturze. Książki, filmy, gry komputerowe i planszowe pełne są czarów, potworów i nadprzyrodzonych zjawisk. Grecko-rzymska mitologia jest dziś popularna, postacie mitologicznych herosów, bogów i potworów są wykorzystywane bardzo często. Zupełnie inaczej wygląda kwestia antycznej magii, której mało kto poświęca uwagę. Bardzo często wspomina się o popularności magii w średniowieczu - głównie ze względu na liczne procesy, egzekucje domniemanych osób praktykujących czarną magię oraz ostry sprzeciw Kościoła wobec czarów. Wykorzystywanie nadprzyrodzonych mocy było jednak popularne już w świecie antycznym, zaś średniowiecze i późniejsze epoki jedynie kontynuowały trwające i narastające aż po dziś dzień zainteresowanie magią ${ }^{1}$.

\section{Magia w STAROŻYTNYM RZYMie}

Starożytni pisarze bardzo chętnie sięgali po motywy związane z nadprzyrodzonymi zjawiskami, po mroczne historie o duchach i czarach. Były one wykorzystywane zarówno w poezji, jak i w prozie. Mogły one pełnić rozmaite funkcje. Były przestrogą przed gniewem bogów, a równie często spełniały jedynie rolę ozdobnika, miały się podobać lub rozśmieszyć. Trudno jest, na podstawie świadectw literackich, ocenić jakie było rzeczywiste podejście ludzi starożytnych do magii. Czy traktowali ją jedynie jako zabobon, coś co mogło przestraszyć prostych, niewykształconych ludzi? Przeciwko tej tezie przemawia bardzo częste wykorzystanie tematyki magii przez najwybitniejszych antycznych pisarzy (jak choćby Lukan, Wergiliusz, Horacy). Gdy dodamy do tego niezwykła popularność wszelkiego rodzaju ochronnych amuletów, miłosnych i uzdrowicielskich napojów i maści, cały szereg zaklęć zapewniających bezpieczeństwo i ochronę przed duchami, widzimy obraz społeczeństwa, $\mathrm{w}$ którym praktykowanie magii było niezwykle popularne. Z drugiej strony, cała plejada znakomicie wykształconych poetów i prozaików wyśmiewała zabobon i osoby praktykujące magię (Petroniusz, Apulejusz). W niniejszym artykule pragnę w sposób syntetyczny przedstawić obraz czarownic w rzymskiej literaturze, zwracając uwagę zarówno na te postaci, które przerażały, jak i na te, które miały czytelników rozbawić.

Pierwszą interesującą kwestią jest sam fakt funkcjonowania magii w Rzymie. Dozwolone było oczywiście stosowanie wszelkiego rodzaju amuletów oraz szukanie pomocy u bogów poprzez modlitwy, ofiary i zaklęcia, inne rodzaje magii (czarna magia, nekromancja, magia miłosna) były zakazane ${ }^{2}$. Wspomina o tym między innymi Apulejusz, w swojej Apologii, podkreślając, iż tego rodzaju praktyki są niebezpieczne, ściagają na ludzi gniew bogów. Określa wszelkiego rodzaju magię jako potworna, zaś osoby praktykujące ją to zbrodniarze, którzy ukrywają się i nocą odprawiają swoje czary: „Prawdziwa magia - o ile słyszałem - jest to zajęcie ścigane przez prawo i już od dawna zakazane w dwunastu tablicach z powodu jej tajemniczego działania na

\footnotetext{
G. Klaniczay, A cultural history of Witchcraft, "Magic, Ritual and Witchcraft" 2010, vol. 5, nr 2, s. 188-212.

T. Sapota, Magia i religia w twórczości Lucjusza Apulejusza z Madaury, Kraków 2001, s. 13.
} 
urodzaje; jak jest potworna i straszna, tak też jest i ukrywana; praktykują ją nocami, chowają w ciemnościach, chronią przed świadkami, a zaklęcia wymawiają szeptem" ${ }^{3}$.

Przechodząc do opisu czarownic muszę jeszcze wspomnieć, iż wybór kobiet praktykujących magię nie był przypadkowy. Bardzo mało jest bowiem świadectw, mówiących nam o czarodziejach czy magach. Owszem, w literaturze rzymskiej często możemy spotkać się z postaciami kapłanów czy wieszczów, jednak oni wykonują swe czynności zgodnie z prawem, pomagając ludziom i nie narażając się na gniew bogów. Czarna magia, zarówno w poezji i prozie, jak i w sztuce ${ }^{4}$, jest domeną kobiet. Co więcej, zazwyczaj są to kobiety stare i odrażające, nierzadko nie stroniące od alkoholu i uciech cielesnych. W łacinie osoby praktykujące ten zakazany rodzaj magii nazywane były praestigiatrix (czarodziejka, oszustka, istnieje też rodzaj męski praestigator - czarodziej, żongler, oszust), saga, sagana, Thesalla (Tessalijka, od krainy uważanej za najbardziej związaną z czarną magia, Tessalii), strix (strzyga, nocna wiedźma porywająca dzieci lub zwłoki), lamia ${ }^{5}$ (czarownica pożerająca dzieci, od mitycznej Lamii) ${ }^{6}$. Warto podkreślić, że tylko jedno z wymienionych określeń posiadało formę męską (wspomniany praestigator), jednak pojawiała się ona bardzo rzadko (głównie u Plauta). Jeszcze jednym, dość istotnym i wartym nadmienienia faktem jest to, iż czarownice w literaturze rzymskiej były postaciami wyłącznie negatywnymi. Nie było rozróżnienia, które znamy dziś, czyli podziału na dobre wróżki i złe wiedźmy. Czarna magia, którą parały się kobiety była zakazana, ich postępowanie wzbudzało strach ludzi i gniew bogów. Trudno byłoby się doszukać jakiegokolwiek pozytywnego elementu w opisywanych czarownicach. Nic dziwnego, że wywoływały tylko dwa rodzaje emocji: strach, gdy pojawiały się siejąc zniszczenie i zagrażając ludziom, lub śmiech, gdy ich magia nie zadziałała, lub gdy trafiły na silniejszego lub bardziej przebiegłego przeciwnika.

\section{Czarownice lukana, Apulejusza i Horacego}

Pierwszą z przerażających czarownic ukazuje w swojej Wojnie domowej Marek Anneusz Lukan. Epopeja opowiada dzieje wojny pomiędzy Cezarem a Pompejuszem, zakończonej w roku 48 przed Chrystusem bitwą pod Farsalos (stąd inny tytuł dzieła - Farsalia). Interesującą nas postacią jest czarownica Erichto, która pojawia się w VI księdze Farsaliów. Czarownica zamieszkuje wspominaną już przeze mnie Tessalię, krainę czarów i czarownic. Jest znana w okolicy ze swego okrucieństwa i wielkiej mocy ${ }^{7}$ Potrafi kontaktować się ze światem Podziemnym, jest nekromantką (przyzywa dusze zmarłych i wykorzystuje je do swoich celów). Syn Pompejusza, Sekstus udaje się do niej po wróżbę dotyczącą wojny. Ponadto, wiedźma nie lęka się gniewu bogów, zaś ci wolą nie wchodzić z nią w konflikty. Erichto mieszka samotnie w pustych grobach, praktykuje magię tylko nocą. Boją się jej nawet nocne stworzenia - wilki i sowy. Przerażającego obrazu dopełnia wygląd Erichto - jest odrażająca, bardzo chuda, trupio blada, ma potargane szaty i rozczochrane włosy ${ }^{8}$. Do swoich czarów wykorzystuje zwłoki, które bez skrupułów wykopuje z mogił i rozszarpuje na kawałki. Błądzi po cmentarzu w poszukiwaniu zwłok do swoich magicznych praktyk. Zabiera trupy z grobów, ściagga wisielców z szubienic, zbiera gorące popioły ze stosów. Jeżeli potrzeba jej świeżej krwi, nie waha się zabijać. Czarownica zdecydowanie wzbudza strach, cała scena jest mroczna i pełna grozy 9 .

3 Apulejusz, Apologia czyli w obronie własnej księga o magii, Warszawa 1975, I, 47.

4 Pollard E. A., Witch-Crafting in Roman Literature and Art New Thoughts on an Old Image, "Magic, Ritual and Witchcraft" 2008, vol. 3, nr 2, s. 154.

5 R. H. Robbins, Encyklopedia czarów i demonologii, przeł. M. Urbański, Warszawa 1998, s. 175.

E. E. Burriss, The Terminology of Witchcraft, "Classical Philology" 1936, vol. 31, nr 2, s. 138.

Opis czarownicy Erichto i jej magicznych praktyk: Lukan, Wojna Domowa, VI, 510.

A.Wołek, Erichto - strzyga, nekromantka, lamia?, "Nowy Filomata” 2010, nr 14, s. 206.

D. Ogden, Magic, witchcraft and ghosts in the Greek and Roman Worlds, Oxford 2002, s. 123. 
Podobny opis czarownic przedstawia inny łaciński pisarz - Lucjusz Apulejusz z Madaury (urodzony około $125 \mathrm{r}$., data śmierci jest nieznana). Jego dzieło Metamorfozy albo Złoty Osioł to pełna przygód opowieść o młodym mężczyźnie-Lucjuszu, przypadkowo zamienionym w osła. Bohater w oślej skórze przemierza świat, spotykając się z najrozmaitszymi ludźmi, często praktykującymi czary lub takimi, którzy padli ich ofiarą. Już w pierwszej księdze autor wprowadza czytelnika w świat magii i grozy ${ }^{10}$, tłem demonicznej historii po raz kolejny czyniąc Tessalię, uważaną przez ludzi antyku za krainę czarów. Bohater Metamorfoz Lucjusz spotyka podczas swojej wędrówki ${ }^{11}$ dwóch kłócących się podróżnych. Jeden z nich zabrania swemu kompanowi kontynuowania pewnej opowieści. Lucjusz zachęca go jednak do mówienia i Arystomenes - bo tak ma na imię ów podróżnik, wykłada mu całą historię od początku. Arystomenes był handlarzem - usłyszawszy, że w Tessalii można nabyć tani i dobry ser, udał się w podróż w tamte rejony. W Tessalii spotkał swojego dawnego przyjaciela Sokratesa. Mężczyzna był zmęczony i wygłodzony. Arystomenes zaoferował mu pomoc, a wówczas Sokrates opowiedział mu swoje dzieje. Podczas podróży został napadnięty i okradziony przez zbójców. Błąkał się nie mając niczego, gdy pod swój dach przygarnęła go pewna karczmarka Meroe. Sokrates z braku innego wyboru, nie spodziewając się niczego złego, przyjął jej pomoc i trafił do domu tej: „starki wprawdzie, ale jeszcze mocno jurnej ${ }^{21 "}$. Meroe chętnie przygarnęła także Sokratesa do swojego łóżka. Po jakimś czasie okazało się, że kobieta nie zamierza pozwolić mu odejść - musiał on więc nie tylko zaspokajać jej erotyczne potrzeby, ale także pracować i oddawać jej wszystko, co zarobił. Arystomenes pyta swojego kompana, dlaczego po prostu nie uciekł od kobiety. Wówczas Sokrates opowiada mu o nadzwyczajnych umiejętnościach Meroe, która miała być czarownicą. Pomimo, iż kobieta praktykowała magię, mężczyźnie udało się uciec i wydawało się, że kochanka pogodziła się z jego odejściem. Arystomenes postanawia mu pomóc, obaj udali się na nocleg do karczmy. Nocą odwiedzily ich jednak Meroe, żądna zemsty na niewiernym kochanku, oraz jej pomocniczka Pantia. Czarownice przybyły do śpiących mężczyzn zaraz po północy. Zjawiły się nagle, nie wiadomo skąd. Zaatakowały śpiącego mężczyznę pomimo obecności jego kompana. Rozcięły szyję Sokratesa i wlały jego krew do naczynia, po czym opuściły izbę. Po ich ataku ofiara obudziła się blada, wyczerpana i nie pamiętając niczego, zmarła następnego dnia. Jeśli chodzi o opis czarownic - jest on bardzo podobny do tego przedstawionego przez Lukana: kobiety są stare, brzydkie, a wręcz odrażające, jednocześnie dysponują przerażającą moca, której nie przeciwstawiają się nawet bogowie. Są okrutne i za nic mają ludzkie życie, wykorzystując wszystko wokół do swoich celów.

Bardzo podobna jest sytuacja z czarownicą Kanidią z V epody Horacego (Quintus Horatius Flaccus, żył w latach $64-8$ przed Chrystusem). W utworze tym czarownica schwytała małego chłopca i zakopała dziecko żywcem w ziemi, tak, że wystawała mu tylko głowa. Kobiety czekały aż dziecko umrze, by potem wykorzystać jego narządy do swoich czarów. Opis Kanidii powtarza motywy z opisu Meroe i Erichto: charakterystyczne są nieuczesane włosy oplecione wężami ${ }^{13}$, blada cera, odrażający wygląd. Poza tym w przypadku Kanidii pojawia się także wątek erotyczny - otóż wnętrzności chłopca są czarownicy potrzebne, aby sporządzić poculum amori ${ }^{14}$ - napój miłosny. Kanidia chce bowiem, aby powrócił do niej mężczyzna o imieniu Warus ${ }^{15}$. Warto tu zwrócić uwagę na fakt, iż wszystkie te - tak podobne do siebie - czarownice z rzym-

\footnotetext{
10 D. W. Leinweber, Witchcraft and Lamiae in "The Golden Ass", "Folklore" 1994, vol. 105, s. 77.

11 Apuleius, Metamorphoseon libri XI, Leipzig 1931, księga I.

2 Tamże, I, 7.

3 Horatius, Dzieła wszystkie, t. 1: Ody i epody, Wrocław 1986, Epoda V, 15.

4 Tamże, 38.

Tamże, 73.
} 
skiej literatury, wzorowane były na postaciach z literatury greckiej - przede wszystkim na Kirke z Odysei Homera i Medei Eurypidesa ${ }^{16}$.

Podobne opisy kobiet praktykujących czarną magię znaleźć możemy również u Petroniusza (Gajusz Petroniusz zwany Arbitrem, żył w latach 27-66) w Satyrykach. Przedstawia on m.in. istoty, które porywają zwłoki. Historia ta jest częścią Uczty Trymalchiona i została opowiedziana przez samego gospodarza. Trymalchion przekazuje historię z czasów swojej młodości, gdy podczas pogrzebu jednego z niewolników pojawiły się strzygi ${ }^{17}$. Gromada tych głośnych istot zebrała się wokół zwłok i odpędziła stamtąd żywych. Strzygi nie dały się odegnać, ukradły ciało, a na jego miejsce podrzuciły słomianą kukłę. Raniony podczas walki z nimi człowiek, zmarł po kilku dniach nękany atakami apopleksji. Cała opowieść zakończona jest przestroga, iż należy wystrzegać się przebiegłych nocnych czarownic, które nie zawahają się przed niczym, by tylko zdobyć to, czego potrzebują ${ }^{18}$. Szczęśliwie dla młodego Trymalchiona, wiedźmom wystarczyły porwane zwłoki i nie uprowadziły nikogo z żyjących.

\section{SATYRYCZNE UJĘCIA CZAROWNIC}

Tak przerażające opisy czarownic i ich nocnej działalności były w literaturze łacińskiej dość powszechne. Zdarzało się jednak również, iż autorzy próbowali żartować z tego typu zjawisk. Takie sytuacje widzimy we wspomnianych już Metamorfozach Apulejusza. Niekiedy stare, lubieżne czarownice, za wszelką cenę polujące na młodych chłopców, są przez niego wyśmiewane ${ }^{19}$. Z jednej strony, kobiety parające się magią są straszne, jednak z drugiej, jest nadzieja dla uczciwych ludzi. Mogą oni uciec się do bóstwa, które będzie dla nich ochroną i wskaże właściwą ścieżkę ${ }^{20}$. Autor pozwala sobie zatem na przedstawienie kilku komicznych postaci, które parają się czarami. Są to zawsze kobiety, które wykorzystują magię, aby zyskać młodych kochanków, bądź też żony, które za pomocą magii, mniej lub bardziej skutecznie, tuszują swoje zdrady. Warto wspomnieć, iż kobiety zdradzające swoich mężów bardzo często - w literaturze łacińskiej-uciekały się do pomocy czarownic. Efekty tego były bardzo różne - czasami udawało się udobruchać zdradzonego za pomocą magii, czasami zaś żona i jej pomocniczka - wiedźma były przez niego przepędzane. Jak wspominałam we wstępie tego artykułu, stare, brzydkie kobiety były - szczególnie w rzeźbie - równie często utożsamiane z czarownicami, jak i z pijaczkami. Obraz pijanej, lubieżnej czarownicy również należy raczej do komicznych, niż przerażających wizji - kobiety takie nie były w stanie poprawnie korzystać ze swojej magii. Warto także zwrócić uwagę na sam charakter dzieła Apulejusza, które jest przecież przepełnione przygodą i humorem, często brutalnym. Nic dziwnego, że pojawiające się tutaj postacie nie są jednoznaczne, że mogą w jednej chwili przerażać, w drugiej śmieszyć, ostatecznie zaś pouczać i wskazywać, jak należy postępować, a jakich dziedzin nauki, i jakich osób lepiej unikać. Podobnie jest w przypadku Satyrykonu Petroniusza - wszelkie przytaczane tam historie o wilkołakach, czarownicach i strzygach opowiadane są podczas uczty wyzwoleńców. Ci niewykształceni ludzie z pełnym przekonaniem i przerażeniem wymieniają się doświadczeniami w kwestii magii oraz nadzwyczajnymi przygodami. Biorąc pod uwagę stosunek autora do tych niewykształconych, wręcz głupich ludzi, którzy przypadkiem zdobyli majątki, można przypusz-

16 C. E. Manning, Canidia in the Epodes of Horace, "Mnemosyne" 1970, vol. 23, nr 4, s. 398.

17 Petronius, Satyricon, London 2005, LXIII.

18 Tamże.

19 W. E. Stephenson, The Comedy of Evil in Apuleius, "Arion" 1964, vol. 3, nr 3, s. 87.

20 U Apulejusza takim bóstwem jest Izyda - to ona ostatecznie ratuje głównego bohatera i jest tym „,właściwym bóstwem", do którego należy się zwrócić. Więcej na ten temat: W. E. Stephenson, dz. cyt., s. 93; oraz D. W. Leinweber, dz. cyt., s. 81 . 
czać, iż historie o czarach przytaczane są tu w kontekście wyśmiania zabobonności prostych ludzi.

Bardzo interesujący przykład wyśmiewania czarownic znajdujemy u Horacego. Poeta ukazał swój kunszt, przeobrażając budzące grozę przedstawione w Epodach czarownice w tchórzliwe staruszki w Satyrze III (Kiedyś byłem pniem figi). Utwór ma postać monologu, przedstawionego przez stojący w ogrodzie posąg boga Priapa ${ }^{21}$. Opowiada on czytelnikowi swoją historię, wspominając czasy, gdy był jeszcze drzewem, następnie zaś przechodzi do opisu tego, co widzi nocą w ogrodach. Największym nieszczęściem są według niego krążące tu nocami czarownice - Kanidia i Sagana. Następuje opis czarownic - bardzo podobny do tego, który przedstawił Horacy w swoich Epodach, jak również podobny do opisów Lukana czy Apulejusza. Wiedźmy pojawiają się, gdy tylko wzejdzie księżyc. Poszukują kości i trujących roślin do przyrządzania mikstur. Biegają po ogrodach boso, w poszarpanych ubraniach, nieuczesane. Są blade, bezzębne i odrażające, zupełnie jak te opisywane wcześniej. Mają ze sobą woskowe i wełniane kukły, próbują przyzywać duchy, lejąc krew w wykopane w ziemi doły. Wzywają na pomoc bóstwa Podziemia i nie dają narratorowi opowieści spokoju. Mogłoby wydawać się, że mamy do czynienia z podobnym do wcześniejszych strasznym opisem nocnych czarów. Jednak posag Priapa nie zamierza zostawić czarownic w spokoju i pozwolić bezcześcić ogrodu, który ma pod opieką. Nie boi się czarownic i postanawia je przepędzić. Widząc go obie wiedźmy krzyczą i przerażone uciekają gubiąc po drodze zioła, lalki i inne narzędzia. Drewniany Priap kpi z nich i ich praktyk, pokazując, że tak naprawdę są jedynie starymi, tchórzliwymi kobietami, które próbują posiąść moce dostępne jedynie bogom. Cała scena sprawia wrażenie zdecydowanie komicznej - wystarczy wyobrazić sobie „straszliwe" czarownice, którym nocne praktyki przerywa ożywiony posag bóstwa z wielkim członkiem, strasząc kobiety, a potem naśmiewa się, komentując całą sytuacjęjako świetną zabawę.

\section{Podsumowanie}

Magia i osoby zajmujące się nią były w starożytnym Rzymie niezwykle popularne. Tematyka ta doskonale wpisywała się w antyczny świat pełen herosów, potworów i boskich ingerencji w życie zwykłych śmiertelników. Nic zatem dziwnego, że chętnie sięgali po nie pisarze, wplatając związane z nimi wątki do swoich dzieł. Czarownice spotkać możemy w różnych dziełach, zarówno w prozie i poezji. Sięgają po nie najwybitniejsi pisarze rzymscy, jak Horacy, Owidiusz, Petroniusz, Apulejusz czy Lukan. Niezależnie od tego, czy ci dobrze wykształceni, pochodzący z elit twórcy wierzyli w istnienie magii, czy wykorzystywali ją by uatrakcyjnić swe dzieła, czarownice były częstymi bohaterkami na kartach ich utworów. Czasami były one jedynie ozdobnikiem i pomagały ukazać kunszt pisarski poety, niejednokrotnie wprowadzały czytelnika w klimat grozy i tajemniczości. Zdarzało się również, że mogły rozśmieszać lub poprzez śmiech pouczać. Czarownice omówione w niniejszym artykule nie są oczywiście jedynymi, które występują w całej literaturze Rzymian. Wybrałam utwory, w których opisy były najpełniejsze i w których czarownice odgrywały znaczącą rolę. Pewnym jest, iż pomimo wykształcenia i zdrowego rozsądku, także wśród elit rzymskich panowała pewnego rodzaju obawa przed tym, co nieznane, niezrozumiałe, nadprzyrodzone. Aura tajemniczości, która spowijała nocne praktyki wiedźm, jak również ich odrażający wygląd, pociąg do seksu i - często również - do alkoholu sprawiły, że czarownice stały się wdzięcznym tematem i postaciami, które mogły jednocześnie przerażać i bawić.

21 Priap jest synem Dionizosa. Czczony w Grecji i w Rzymie bóg płodności, zapewniający urodzaj. Jego posagi z wielkim członkiem w stanie erekcji ustawiano w ogrodach - miało to zapewnić dobre plony i chronić ogrody przed złodziejami. P. Grimal, Stownik mitologii greckiej i rzymskiej, (red.) J. Łanowski, Wrocław - Warszawa - Kraków, 1990, s. 302. 


\section{LITERATURA PODMIOTU}

Apuleius, Metamorphoseon libri XI, (ed.) R. Helm, Leipzig 1931.

Apulejusz, Apologia czyli w obronie własnej księga o magii, przekł. J. Sękowski, Warszawa 1975.

Horatius, Dzieła wszystkie, t. 1: Ody i epody, (red.) O. Jurewicz, Wrocław 1986.

Lucanus, Belli civili libri decem, (ed.) C. Hosius, Leipzig 1913.

Petronius, Satyricon, (ed.) J. Henderson, London 2005.

\section{LITERATURA PRZEDMIOTU}

Burriss, E. E., The Terminology of Witchcraft, "Classical Philology" 1936, vol. 31, nr 2.

Carus P., The history of the devil and the idea of evil from the earliest times to the present day, Londyn 1900.

Grimal P., Stownik mitologii greckiej i rzymskiej, (red.) J. Łanowskiego, Wrocław - Warszawa - Kraków, 1990.

Klaniczay G., A Cultural History of Witchcraft, "Magic, Ritual and Witchcraft" 2010, vol. 5, nr 2.

Kowalski P., Zwierzoczłekoupiory, wampiry i inne bestie, Kraków 2000.

Leinweber D. W., Witchcraft and Lamiae in "The Golden Ass", "Folklore" 1994, vol. 105.

Manning C. E., Canidia in the Epodes of Horace, "Mnemosyne" 1970, vol. 23, nr 4.

Ogden D., Magic, witchcraft and ghosts in the Greek and Roman Worlds, Oxford 2002.

Pollard E. A., Witch-Crafting in Roman Literature and Art New Thoughts on an Old Image, "Magic, Ritual and Witchcraft" 2008, vol.3, nr 2.

Robbins R. H., Encyklopedia czarów i demonologii, przekł. Marek Urbański, Warszawa 1998.

Sapota T., Magia i religia w twórczości Lucjusza Apulejusza z Madaury, Kraków 2001.

Stephenson W. E., The Comedy of Evil in Apuleius, "Arion" 1964, vol. 3, nr 3.

Wołek A., Erichto - strzyga, nekromantka, lamia?, „Nowy Filomata” 2010, nr 14.

\section{STRESZCZENIE}

Niniejszy artykuł pokazuje najważniejsze i najbardziej rozbudowane obrazy czarownic w literaturze starożytnego Rzymu. Problem magii i podejścia do praktykujących ją osób był w antyku bardzo powszechny. Wierzono, że nocą odprawia się czarną magię, zakazaną przez prawo i bogów, magię, która szkodzi żyjącym i sprowadza na nich zgubę. Co ciekawe, osobami praktykującymi magię w antyku były głównie kobiety, zaś ich opisy zaliczyć należy do skrajnie negatywnych. Czarownice były brzydkie, stare i lubieżne, jednocześnie zaś potężne i przerażające. Nic dziwnego, że pisarze starożytnego Rzymu podejmowali chętnie temat czarów, przedstawiając parające się nimi kobiety na dwa sposoby - mogły czytelnika przerażać lub rozśmieszać. Przyglądając się dziełom m.in. Apulejusza, Lukana, Petroniusza i Horacego, możemy zaobserwować oba z wymienionych obrazów czarownic i uświadomić sobie, jak popularny, chętnie powielany i przetwarzany był to motyw.

Słowa kluczowe: literatura antyczna, magia, czarownice, satyra, przerażający, portret

\section{Terrifying and Satirical Representations of Witches in Latin Literature}

\section{Summary}

This article shows the most important and the most powerful images of witches in the literature of Ancient Rome. The problem of magic and magic practitioners was very common in antiquity. People believed that during the night black magic was practiced, magic which was prohibited by law and the gods, and that harmed living creatures and even caused their death. Interestingly, it was women who predominantly practiced magic in antiquity. Needless to say, they were portrayed in an extremely negative way: witches were ugly, old and lascivious, but at the same time powerful and frightening. It is no wonder that the writers of Ancient Rome willingly touched upon the topic of spells, and presented witches in two ways: either to frighten or amuse the reader. Looking at the works of Apuleius, Lucan, Petronius and Horace, we in the first place see that both modes of representations were equally popular. We also realize how popular this motif was and how often it had been used and transformed.

Key words: ancient literature, magic, witches, satire, scary, portrait 